The Return of Burlesque: Comic Forms in Contemporary Ukrainian Literature, $1985^{-2010}$

Author: Rostyslav Semkiv

Source: Kyiv-Mohyla Humanities Journal 2 (2015): 109-120

Published by: National University of Kyiv-Mohyla Academy

http://kmhj.ukma.edu.ua/ 


\title{
The Return of Burlesque: Comic Forms in Contemporary Ukrainian Literature, $1985^{-2010}$
}

\author{
Rostyslav Semkiv \\ National University of Kyiv-Mohyla Academy, \\ Department of Literature
}

\begin{abstract}
Burlesque as a literary device can serve for satirical purpose, but its main function is revealed in the provocation of carnivalesque ambivalence. Unlike satire, where an author remains serious, carnival laughter captures everyone, including its provocateur. This is exuberant laughter that affirms the joyful fact of very human existence. The use of burlesque in Ukrainian literature does not refer to a certain epoch, but forms a continuous and powerful tradition. In the middle of the 198 os, with the liberalization of Ukrainian society, literature steadily turned away from a purely utilitarian role, and burlesque returned, as a device of free and unrepressed laughter. The "BuBa-Bu" literary group, Yuri Vynnychuk, Les Poderviansky, Mukhailo Brynykh most actively elaborate burlesque in their writings, either in a carnival context, or as a device of satire. Thus, the burlesque tradition is quite visible and influential in contemporary Ukrainian literature.
\end{abstract}

Key Words: burlesque, carnival laughter, satire, contemporary Ukrainian literature.

\section{(7)}

In the second half of the 1980s authoritarian Soviet ideology cracked and was successfully challenged by exuberant Western liberalism. Outside the realms of sophisticated critical theory, millions of people chose not to escape from freedom, but passionately advanced to the almost unknown for them ideals of an open society. After the destruction of the Berlin Wall in 1989 and the fall of the USSR in 1991, the Soviet regime collapsed, and its version of Marxist ideology nearly ceased to exist. Literature, as the other arts, all of a sudden appeared as a domain of free creation, no more a servant for consciousness improvement. That was also the time when postSoviet literatures once again learned how to laugh freely, and steadily developed different and rich forms of laughter.

Ukrainian literature for centuries possessed a quite diverse tradition of carnival burlesque, humour and satire, though severe control of the Soviet regime considerably narrowed the scope of literary laughter to a few permitted forms. In fact, an authoritarian system always considers the majority of comic devices and genres too uncontrolled, and thus dangerous. Only overt and overtly directed satire is welcome, because it can be used as another tool of ideological struggle; yet light popular humour is permitted, as it is almost harmless in the locality of its critique.

Meanwhile, liberalism unchains all possible forms of laughter, and gives way to the development of buoyant comic literature. During the last decade and a half of the previous 2oth century almost all notable Ukrainian authors fell back upon various comic forms. The fiction 
and poetry of Yuri Andrukhovych, Mykhailo Brynykh, Oleksandr Irvanets, Viktor Neborak, Les Poderviansky, Yurko Pozaiak, Svitlana Pyrkalo, Yuri Vynnychuk, and Serhi Zhadan are vividly and visibly burlesque, while the more critical Volodymyr Dibrova, Yuri Izdryk and Oksana Zabuzhko exploit more sordid forms of irony and sarcasm. Their literature became explosive and thus far more interesting. In fact, it at last gained its real reader. The impact of this profound change cannot be underestimated. While analysing the contemporary scope of literary laughter, theory and its adepts should be more precise in defining various comic forms, which literally display the liberation of the post-Soviet and postcolonial mind.

\section{Carnival and Satirical Burlesque}

Satire as propaganda tool and humour as entertaining gesture were actively exploited in the literature of the Soviet period. Meanwhile burlesque was used only as a device for satirical laughter. This reduction of its spectrum almost totally purged the initial function of burlesque, which vividly appears in the context of carnival. One of the most interesting Soviet theorists, Mikhail Bakhtin, was marginalized in a regional university, as was his theory of carnival laughter. Both were too free for Soviet criticism. At the same time, Bakhtin's observations are crucial for understanding the variety of comic forms in contemporary literature. Thus, we should start with the return of burlesque as a notion in its previous far richer meaning.

Traditionally burlesque is defined as a device of style lowering that produces comic effect. In this status it performs a subordinate role, and thus cannot be treated as the central notion of a certain poetics. On the contrary, in this short essay we try to prove that the role of this device is underestimated. The tradition of burlesque poetics is quite vivid, especially in Ukrainian literature. This tradition is not less powerful than other trends in Ukrainian writing of the 19th2oth centuries, and even more influential in comparison to, for example, intellectual prose or women's writing. In the great number of known Ukrainian works of literature burlesque does not perform a satirical function. Its function is older and more established and, we dare say, natural.

To define burlesque we should consider two restrictions. One is logical, and the other deals with the history of the notion. In general reception burlesque, first of all, consists in retelling of a sublime or "high" plot in a trivial everyday and even obscene language. It is the realization of a "conscious discrepancy of content and form, the use of a low style instead of a high one." ${ }^{1}$ At the same time burlesque, unlike parody, is not so obviously keen on the alteration and subsequent negation of any original. The burlesque gesture of mocking reversion is total, and not aimed at a certain subject. It is a carnival gesture that points out the general ambivalence of being. This way burlesque rarely can be seen as a separate literary device. This is the basic carnival element, which demonstrates the potential possibility to mock and overthrow literally everything. Spacious laughter that appears as a reaction to burlesque mockery is not concerned with the specific "reversed" object, but rather will sign the simple joy of being, which is rooted 
in the understanding, even the instant comprehension, of the vital movement that finally dominates over death.

Historically, the notion appears in the 16 th-17th centuries in classicist poetics, which underline the importance of high and low style differences. ${ }^{2}$ On the other hand, we can already characterize "Batrachomyomachia" as a burlesque poem. It is not a parody in the modern sense, as far as it was scarcely aimed at the mocking of Homer or the genre of an epic poem. It was more likely the gesture of innocent joyful reversal, mocking carnival manipulation in which everything worthy should be made ambivalent. This way burlesque comic reversal does not compromise an original, but on the contrary marks it worthy and important for a carnival game. The most contemporary works on parody apologize this phenomenon. Parody does not only negate, but also underlines and comprehends a certain original, and thus can be treated as "one of the major forms of modern self-reflexivity, a form of inter-art discourse." ${ }^{3}$ Meanwhile, parody is a genre, and foresees a broad quotation and recognition of an original. Burlesque, on the contrary, just reverses something that is given here and now. We can say that burlesque is an instant parody, whose object can be given in the same text. This way, burlesque forms the basis for any parody; it can, but ought not to serve a satirical aim. It can function independently, stressing the connection with the realm of carnival laughter.

Mikhail Bakhtin defines burlesque precisely in this sense. For him it is a notion connected with a carnival, and it does not serve as a satirical device, or relate to a certain historical epoch. For Bakhtin, burlesque is a literary analogue of grotesque, the notion which marks the general ambivalence of everything inside the carnival. Grotesque is the demonstration of dynamic body, language or any other phenomenon, when their being is touched with disintegration. At the same time, this destruction of form, even if it is monstrous and disproportional, encloses the features of a renewal and revival. Bakhtin considers that in romanticism grotesque is understood as a monstrous paradox, but early carnival grotesque is always ambivalent, and soundly manifests an eternity of being. Carnival grotesque is a joyful grotesque. In literature it is expressed in burlesque imagery, motives and language.

For Bakhtin, the satirical effect of the carnival and thus burlesque is deliberate. He asserts: "We should stress the important peculiarity of folk festive laughter. It is also aimed at those who are laughing. The folk does not exclude itself from the whole world that exists in the process of formation. It is also not fulfilled, dies, but is reborn and renewed. In this we see one of the most crucial differences of folk festive laughter from the pure satirical laughter of the new time. The pure satirist, who knows only a negating laughter, sets himself aside from the phenomenon that is being laughed at. He contrasts himself to it, and this destroys the wholeness of the comic effect. The comical (negating) phenomenon becomes a partial one. On the contrary, folk ambivalent laughter expresses the point of the whole world that exists in formation. The one who laughs also belongs to this world." ${ }^{4}$

2 Margaret Rose, Parody: Ancient, Modern, and Post-modern (Cambridge: Cambridge University Press, 1993), 54 .

3 Linda Hutcheon, $A$ Theory of Parody (London, New York, 1991), 2.

4 Mikhail Bakhtin, Tvorchestvo Fransua Rable i narodnaia kultura srednevekovia i Renesansa [François

Rabelais and Folk Culture of the Middle Ages and Renaissance] (Moscow: Khudozhesvennaia 
Soviet criticism was obsessed with a utilitarian view of literature as a tool for ideology. Bakhtin then proposes a really revolutionary idea, when he asserts that carnival laughter could not be narrowed to be aimed at satire. In fact, he stresses the right of literature and all of human culture to be non-utilitarian, deliberate, deprived of any certain aim, except the general expression of freedom and the joy of living. Burlesque literature implements both these aspirations.

At the same time, we should try to point out a certain incorrectness in Bakhtin's carnival theory. Bakhtin claims that carnival culture almost disappears after the Renaissance. In Romanticism it becomes subjective and transforms into romantic grotesque, which does not allude to renewal and rebirth. ${ }^{5}$ For us this point of view is quite dogmatic. First of all, it ignores the fact that folk carnival tradition exists in its natural environment ${ }^{6}$; then it oversees the birth of several new cultural phenomena, like jazz or, or for example, Antonio Gaudi's architecture, which are both closely connected with carnival. Unlike Classicism, Romanticism did not push burlesque and carnival laughter into the reserve of the low genres. Romantic authors, as Bakhtin argues, really experience their joy of living all alone, and that is called romantic irony. The connection of carnival burlesque with romantic irony is genetic, the same as the ties of the former with satire. In fact, Bakhtin underlines that both satire and dark romantic grotesque rise from the carnival, though substituting the joyful pathos of eternal renewal with the subjective experience of finiteness. Bakhtin does not mention examples of light romantic irony, which we can find in the early writings of Byron, Hoffmann, or Hohol (Gogol). On the contrary, Roman Struc, who is one of the most profound contemporary researchers of romantic irony, underlines exactly the ambivalence of this phenomenon, which fluctuates between "playful aloofness and sympathy, criticism and compassion, serious and mocking tones." 7 Romantic irony, of course, is a more complex communicative device than burlesque, but its connection with carnival laughter is clearly visible. In fact, the romantic theorists, like Fridrich Schlegel, already observed romantic irony in the writings of Cervantes and Shakespeare. Thus there is a certain point somewhere in the late Renaissance, when carnival and the clownish burlesque of Sancho Panza start to coexist with the ironic reflection of Don Quixote.

This way, Romanticism proposes an additional, and more complex variety of the comic (romantic irony), but that does not mean the collapse of the folk carnival tradition, and related burlesque literature. It remains a question of why Bakhtin does not associate with the carnival the typical burlesque laughter of his contemporaries, Ilya Ilf and Yevgeniy Petrov. Of course, we detect other forms of the comic besides burlesque in their writings, but we also cannot deny

literatura, 1990), 17 .

Bakhtin, Tvorchestvo Fransua Rable, 44-48.

6 Though this tradition is significantly narrowed, it exists as an authentic fest, and possesses all carnival features form Bakhtin's theory. In the Ukrainian context we can find a few rather archaic rituals, like pereberiia, vertep, koza or kupala, performed unchanged since very old times. The same is true, if we speak about certain folk elements of the wedding, funeral or wake, which are carried out even inside a contemporary urban culture.

7 Roman Struc, "Pushkin, Lermontov, Gogol: Ironic Modes in Russian Romanticism," in Romantic Irony, ed. Frederick Garber (Budapest: Akadémiai Kiadô, 1988), 246. 
that the tradition of carnival laughter continued to exist long after Romanticism. In fact, this laughter is evident in every period of literature, and in all human culture.

\section{The Ukrainian Burlesque Tradition}

Therefore, we define burlesque as playful and joyful reversion (distortion) of an original phenomenon, which does not anticipate satirical mockery as its principal aim. It is the carnival that forms the natural context for burlesque. Inside this context nothing remains identical, and thus serious. Burlesque provokes joyful laughter, which testifies to the intensive joy of the very fact of human existence. Burlesque does not always laugh at, basically it just laughs.

Alongside with many other literatures, Ukrainian literature hosts a considerable number of burlesque pieces. We can trace the rich tradition of Ukrainian burlesque literature, which cannot be overlooked, and should obviously be addressed for proper understanding of the national literature peculiarity.

Meanwhile, the Ukrainian critical tradition mainly narrows burlesque to Ivan Kotliarevsky's style imitations (kotliarevshchyna), and chronologically encloses it in the first half of the 19th century. ${ }^{8}$ Kotliarevshchyna is neglected as secondary, unoriginal, and weak phenomenon by principal Ukrainian critics Serhii Iefremov, Mykola Zerov, and Dmytro Chyzhevsky. ${ }^{9}$ Nowadays Tamara Hundorova defines as kitsch-like, and thus secondary, the very work of Ivan Kotliarevsky. ${ }^{10}$ The personal style of Kotliarevsky is not always seen as different from the style of his followers. Only at the end of the 2oth century, George Grabowicz asserted the idea of Kotliarevsky's burlesque prolificacy, speaking of kotliarevshchyna as the "initial pathos of vitality."11 Though Grabowicz quotes Bakhtin only once, in the footnote of his work, we definitely note the resemblance in both approaches. Burlesque unfolds primarily as the mechanism of carnival laughter provocation, and has no aim to mock. The subversive function of burlesque laughter, which is later pointed out by professor Grabowicz, is not the original aim of it. This subversion is rather implicit, and can be explored only in comparison with the serious, "high" imperial culture. The literature of a metropolis pushes burlesque "low" genres to margins, in particular to the marginal literature of a colony.

Professor Grabowicz very carefully implies that burlesque in Ukrainian literature of the 18th-19th centuries is not only a transitional phenomenon. He argues: "The initial differential function of the kotliarevshchyna style, i.e. its role in the very context of Ukrainian literature, is not less complex. There is no doubt that this style distinguishes the newest Ukrainian literature from its former stage. At the same time, it continues the old literature in certain aspects (as burlesque,

8 Hryhorii Nudha, ed., Burlesk i travestiia v ukrainskii poezii pershoi polovyny XIX st. [Burlesque and Travesty in Ukrainian Poetry of the First Half of the 1gth Century] (Kyiv: Derzhavne vydavnytstvo khudozhnioi literatury, 1959).

9 Hryhorii Hrabovych, Semantyka kotliarevshchyny [The Semantics of Kotliarevshchyna], accessed December 18, 2014, http://izbornyk.org.ua/hrabo/hr14.htm.

10 Tamara Hundorova, Kitch i literatura [Kitch and Literature] (Kyiv: Fakt, 2008), 92-122.

11 Hrabovych, Semantyka kotliarevshchyny. 
baroque games etc.)." 12 There is a further mention of a "vague recession of this style," but with the remark that this burlesque based style "existed till the time of Khvylovy, and possibly exists even now." 13 Intrinsically we tend to underline that in Ukrainian literature, as in other, but not all literatures, one can observe the existence of a powerful burlesque tradition, which stretches from Ukrainian goliards of the 17 th century ${ }^{14}$ to Ivan Kotliarevsky, Kvitka-Osnovianenko, Mykola Hohol, ${ }^{15}$ from Stepan Rudansky to Ostap Vyshnia, and further on to our days. The connections inside this tradition are evident and undeniable. Folklore laughter influenced the burlesque of the cantors, who influenced Kotliarevsky and Hohol; the latter influenced Vyshnia and so on.

Since the last two centuries the robust tradition of carnival laughter co-exists in Ukrainian literature with sentimental lyrical writing. The last one, however, suits the mourning over national defeats, but also preserves national culture via the cultivation of language and the creation of sovereign imagery. Meanwhile, free laughter, non-cursing curse, non-lethal death that is defeated by vegetative erotica appear in or dominate in the Eneida [Aeneid] by I. Kotliarevsky, Svatannia na Honcharivtsi [Matchmaking in Honcharivka] and Konotopska vidma [The Konotop Witch] by H. Kvitka-Osnovianenko, Vechera na khutore bliz Dikanki [Evenings on a Farm near Dykanka] by Hohol, Tsari [Kings] by T. Shevchenko, Spivomovky [Humoresques] by S. Rudansky, Za dvoma zaitsiamy [In Pursuit of Two Hares] by M. Starytsky, Kaidasheva simia [Kaidash's Family] by I. Nechui-Levytsky, etc. Evidently all these writings remain in the circle of active reading in the 2oth century; they are also studied at school till now. Moreover, these are texts of high value, i.e. they considerably influenced the further development of the national literature, and gained vast popularity through numerous stage and film adaptations.

Carnival tradition is able to overcome the tragic, and turn to ambivalence the most serious phenomena. Death itself here is comic, because it appears only as a link in the infinite and eternal chain of vegetation. Erotic impulse, which can explode with subliminal laughter, ${ }^{16}$ urges the use of burlesque literally in all epochs, notwithstanding the complicity of the historical situation. In 1918 Jaroslav Hašek wrote the first version of his The Good Soldier Švejk that appeared as an antimilitary satire. But in three years the carnival impulse of the plot prevails, and Švejk ceases to be the illustration of class consciousness development, becoming an almost

12 Hrabovych, Semantyka kotliarevshchyny.

13 Hrabovych, Semantyka kotliarevshchyny.

14 In Ukrainian literary history these vagrant students are addressed as mandrovani diaky, the vagabond cantors.

15 The very burlesque style, alongside with Ukrainian topics, provides the possibility without any difficulties to include the early writings of Mykola Hohol (Gogol) into Ukrainian literature. Professor Grabowicz in the quoted work further remarks that Hohol brings a powerful burlesque current into Russian literature. This way the role of Hohol/Gogol is double: he enters Russian literature, but can be also treated as a Ukrainian writer who wrote in Russian.

16 Sigmund Freud analyzes laughter in terms of psychoanalytical economy. While characterizing the simplest naive comic, he writes: "Those expenses, which we perform, as a rule, for deceleration, become unnecessary because of naive speech, and are recompensed with laughter." Zigmund Freid, Ostroumiie i ieho otnosheniie k bessoznatielnomu [The Joke and its Relation to the Unconscious] (Moscow: AST; Minsk: Kharvest, 2006), 216. 
wholly burlesque figure. ${ }^{17}$ At the same time, Ukrainian volunteers in the Austro-Hungarian army (sichovi striltsi), alongside warfare, created a number of burlesque songs, and the carnivalesque Order of Iron Gaff Knights. The urgent need for further belief in humanity appears from the epicentre of the global war. For them to laugh means to be free. And they do not mock an enemy, but just laugh, plunging into carnival from the harsh reality of death and suffering.

Thus, at the beginning of the 2oth century burlesque and carnival culture leave the narrow frames of a printed literature. New means of communication provide the possibility to function in a much vaster spectrum. The above-mentioned song poetry of the sichovi striltsi is not a private initiative of separate individuals, but the steady work of the special propaganda division in the Ukrainian voluntary legion - presova kvatyra (press quarters). In the 2oth century carnival literature is massively replicated, and burlesque laughter bursts through radio, and later television. Such broadcasts for huge auditoriums of listeners/spectators actually produce modern versions of carnival rituals and practices. Burlesque literature thus becomes performative, i.e. it unfolds in various cultural activities, which mirrors old premodern carnivals. This new and vast range of burlesque circulation is its main differential trait in the 2 oth century.

The case of Ostap Vyshnia, as a central figure of Ukrainian burlesque in the 2oth century, is quite exponential. Even his harsh critics Borys Antonenko-Davydovych and Oleksii Poltoratsky recognize the extraordinary popularity of Ostap Vyshnia, even a certain cult of the author. Poltoratsky writes: "We should ascertain that none of the Ukrainian authors gained such fame, except maybe Taras Hryhorovych Shevchenko." 18 Ostap Vyshnia's writings were published in millions of copies, read from the stage, broadcast before and after his repressive imprisonment, and also posthumously.

At the same time, Ostap Vyshnia's laughter initially is not strictly satirical. Since 1921, when he adopted his famous pseudonym, the author wrote in the genre he called usmishky (smiles) or repiashky (burdocks). If these texts mock, then they mock everyone, including the author/narrator. And that is the main feature of carnival laughter according to Bakhtin. Therefore it is total carnival laughter, festive mockery that denies seriousness.

Two dominating devices are used by Ostap Vyshnia to produce laughter, and they are actually associated with burlesque. The author plainly retells us some high ideas (religious, political, cultural etc.) from the common point of view, and he also uses "low" distorted language - surzhyk (a mixture of codified Ukrainian, Russian, and some dialects). This way Ostap Vyshnia literally undermines the pathetic, sublime vision of Soviet reality, which was produced by ideological culture. Though initially it is not a direct critique of the existing system, this carnivalesque counterpoint actually sounds satirical in the context where both free laughter and free thought are marginalized. Carnival ambivalence turns to be dangerous.

17 These three years, since 1918 till 1921, Jaroslav Hašek spent in Russian Red Army. He was highly disappointed with Bolshevik revolution, and turned to skepticism. Then his Švejk became paradoxical and finally burlesque.

18 Oleksii Poltoratsky, “Scho take Ostap Vyshnia?” ["Who is Ostap Vyshnia?”] Nova Heneratsia 2-4 (1930): 28 . 
Thus, not only satirical, but also burlesque voices should be silenced. Ostap Vyshnia this way shared the destinies of Mike Iohansen, Ilya Ilf and Yevgeniy Petrov.

Notwithstanding repressions, carnival tradition survived on the margins of Soviet culture. Bright burlesque elements can be traced in almost all of the films of Oleksandr Dovzhenko, and especially in his novel Zacharovana Desna [The Enchanted Desna]. Burlesque figures appear even in highly pathetic socialist-realist texts, such as Khoma Khaietsky in Praporonostsi [Banner Carriers] by Oles Honchar. Later, in the 196os, burlesque became more visible in the humoresques of Pavlo Hlazovy, tales of Vasyl Symonenko, and novels of Oleksandr Ilchenko and Vasyl Zemliak.

It is important to underline again that burlesque texts become the phenomena of mass culture. To the end of the century the tradition has far from disappeared, on the contrary it widened its spectrum. The humoresques of Ostap Vyshnia and other authors entered the repertoire of stage performers Vitalii Palamarenko, Andrii Sova, the comic show of Shtepsel and Tarapunka. At the same time famous film adaptations appeared: Nich pered Rizdvom [Christmas Eve, 1961], Za dvoma zaitsiamy [In Pursuit of Two Hares, 1961], Vesillia v Malynivtsi [Wedding in Malynivka, 1967], Propala hramota [The Lost Decree, 1972], Vavilon XX [Babylon XX, 1979]. They actualize classical burlesque texts, but also become known through various quotations, which circulate in mass consciousness till today.

\section{Burlesque Ukrainian Literature in the 199os and beyond}

Indestructible burlesque tradition exploded in Ukrainian literature with even more strength, when ideological pressure vanished at the end of the 1980s. Already in 1985 poets Iuriy Andrukhovych, Oleksandr Irvanets, and Viktor Neborak united in a performance group that was called "Bu-Ba-Bu", i.e. "Burlesk-Balahan-Bufonada" ["Burlesque-Carrousel-Buffoonery"].19 In 1987 the group arranged its first poetic readings in public; since then the three poets performed regularly till the end of the 1990s. Their shows, of course, could be treated as a parody of traditional apprehension of a poetical reading, but this minor aim almost dissolves in their general carnavality. There were several other similar groups of poets, as "Chervona fira" ["Red Cart"], "Lu-Ho-Sad", "Nova deheneratsiia” ["New Degeneration"],20 "Propala Hramota" ["The Lost Decree"], ${ }^{21}$ which try to find their own voices in literature, but again, first of all, have taken part in the vast parodying and self-parodying of everything concerned with literature and culture in general.

19 The literary historical facts of the period are better covered in the anthologies: Vasyl Habor, ed., Bu-Ba-Bu (Andrukhovych, Irvanets, Neborak) (Lviv: Piramida, 2007) and Vasyl Habor, ed., Ukrainski literaturni shkoly ta hrupy 6o-9o rr. XX st. [Ukrainian Literary Schools and Groups of the 196os-199os] (Lviv: Piramida, 2009).

20 This group name is parodic towards Mykhail Semenko's avant-guard group of the 1920s Nova heneratsiya [New Generation]. This is very the case, when the parody does not deny, but underlines the original. Poets of the 199os were eager rather to follow Semenko and other Ukrainian futurists.

21 This group was named after the title of Mykola Hohol's burlesque story, which film adaptation appeared in 1972, and became quite popular. 
The same was true for the theatre-cabaret "Ne Zhurys!" ["Don't be sad!"], that also appeared in 1987, and actively performed till 1992. The theatre had several serious scenic appearances, and also produced anti-Soviet satirical pieces, but namely all of its shows enclosed cabaret-like burlesque reprises, which were comprehensively parodic and self-parodic. Yuri Vynnychuk was the main author of the theatre. Later he became perhaps the central figure in all of Ukrainian contemporary literary burlesque.

The climax of all these provocations came in 1990, and then in 1992, when two "Vyvykh" ["Wrench"] alternative art festivals were held in Lviv. Both were genuine carnivals with street performances, obscene shows, and a dominant joyful feeling of regained freedom. The festival of 1992 enclosed the poetic opera "Kraisler imperial" ["Chrysler Imperial"], written and performed by the "Bu-Ba-Bu" group. The group also published a joint book in 1995, which followed personal books of its members: "Litaiucha holova" ["The Flying Head"] by Viktor Neborak in 1990, "Ekzotychni ptakhy ta roslyny" ["Exotic Birds and Plants"] by Iuriy Andrukhovych, and "Tin velykoho klasyka" ["The Shadow of the Great Classic"] by Oleksandr Irvanets, both in 1991. The major bulk of verses in these books, as further novels by Andrukhovych, ${ }^{22}$ use carnival burlesque, i.e. they are comprehensive parodies, and include self-parodying. The verses are proclaimed, and the stories are told by unreliable ridiculous persons. This way, even the most serious thoughts and the most sincere feelings could be treated as ironic and funny.

Yuri Vynnychuk can be treated as the brightest figure in the newest Ukrainian burlesque literature, because of the wide range of his carnivalesque activities. ${ }^{23}$ His role as a script writer of the Ne zhurys! theatre-cabaret was already mentioned, and almost after this project's decline in 1991 Vynnychuk continued his career as pamphlet writer. He delivered political commentaries under the pseudonym of Yuzio Observator [Yuzio the Observer], in the Post-Postup weekly paper. These were colloquial and sometimes even obscene pamphlets, which could be good illustrations of burlesque as basic comic device. One should just retell a kind of "high" topic (for example commentary on presidential elections) with everyday "low" language, add a few indecent expressions and comparisons, and the comic effect appears immediately. But this burlesque can be characterized as less carnivalesque and more satirical. Though Yuzio Observator is funny himself, victims of his criticism are not only ridiculous, but also ugly. This is the point, where, as Bakhtin says, the satirist exempts himself from the criticized world. He is not a part of a carnival any more. Burlesque then turns into a device for a satire.

On the contrary, in his fiction, written between 1992 and 2010, Yuri Vynnychuk uses not satirical, but carnival burlesque, as was in his cabaret reprises for the Ne zhurys! theatre. In his Divy nochi [Night Virgins] cycle he retells a story of a brothel, a place that should be the happiest of spaces for a man; and in Zhytiie haremnoie [Harem Life] he paradises the life of Roxolana into a kind of a pornographic story. Yet we should argue that these are the examples of carnival

22 Andrukhovych's novels Rekreatsii [Recreations, 1992], Moskoviada [Moscowiad, 1993], Perverziia [Perversion, 1996] exploit carnival burlesque as the main device of their poetics. His novels after year 2000 enclose less burlesque; they are more lyrical and serious.

23 For more details see Rostyslav Semkiv, "Yuri Vynnychuk iak tsentralna postat halytskoii burlesknoii literatury," ["Yuri Vynnychuk as the Central Figure of Galician Burlesque Literature,"] in Pislia postmodernizmy, ed. Vira Aheyeva (Kyiv: NaUKMA; Ahrar Media Hrup, 2012), 83-89. 
burlesque, which are not pointed at the mocking of a separate object. These early novels were followed by more accomplished ones: Malva Landa (a woman's name), Vesniani ihry v osinnikh sadakh [Spring Games in Autumn Gardens], and several collections of short prose. All these writings are examples of joyful and comprehensive subversion, stuffed with excesses, eroticism and obscenities. Yuri Vynnychuk cannot give up burlesque imagery even in his newest and most serious novel of 2010, Tango smerti [The Death Tango]. Alongside with pathetic or elegiac moods, while talking about genocide or occupation, he again and again adds a number of purely burlesque episodes, like sex in a library or even death among jam cookers.

His non-fiction works, as Lehendy Lvova [Lviv Legends] or Taiemnytsi lvivskoi kavy [The Secrets of Lviv Coffee], indicate to us another field of Vynnychuk's burlesque activities. Since the early 1980 os he has created several mystifications, which were treated as genuine originals. ${ }^{24}$ The very gesture of taking off a mask, which a mystification reveals, is a vividly carnival one, moreover it is followed by general laughter and comic disgrace. Vynnychuk has also another, gothic, dominant of his style, but burlesque poetics prevail, and form the core of his literary work.

Meanwhile, satire always begins from burlesque lowering, but our attention, almost at once, bypasses the device and reaches the satirical aim. Our laughter can then lose the primary comprehensive joyfulness associated with burlesque, and become bitter or even vicious. We definitely sometimes laugh at various wicked persons or realities, described in the fiction of Oksana Zabuzhko, Irena Karpa, Natalka Sniadanko, or Liubko Deresh, but their laughter has already lost its ties with a joyful carnival environment. At the same time, Voloymyr Dibrova and Yuri Izdryk use not satire, but only ambivalent irony, in which laughter is almost deprived of its initial comic energy. On the other hand, powerful satirical burlesque can be traced in the plays of Les Poderviansky, who uses it as his primary device.

Poderviansky takes a formerly heroic or just serious plot, mainly from Soviet literature, and retells it in colloquial language, filled with numerous harsh obscenities. The foul language of the former empire, which was radically and carefully purged out of officially permitted literature, returns and destroys the heroic sublime. This way, in his plays Poderviansky attacks not only the serious plots of Soviet literature, but also its purist style, as well as the initial grounds of literature as art itself. This is namely anti-literature, produced in a powerful avant-garde gesture: to destroy, and give nothing instead. We can definitely find burlesque lowering here, though never doubt its final aim of satirical destruction. This burlesque does not serve to display the initial joy of living, and does not elaborate carnival contexts any more. The vicious and even demonic laughter of this author is the best example of not carnival, but satirical burlesque.

The last writer we should mention is Mykhailo Brynykh, who started his career already in the new millennium. Once again he uses burlesque to lower a serious plot, but the objects he aims at remain almost untouched by his laughter. Brynykh's actively discussed novel Shakhmaty dlia dybiliv [Chess for Morons] is not so much a parody of a popular book series, but rather a carnival manual that really can teach one to play the game. Chess and chess playing are also not objects for satire here; Brynykh just subverts the whole process of mentorship, depicting himself as comic mentor Doktor Padliuchcho (Doctor Scoundrel). He also uses mixed and impure language (surzhyk), but implies just few obscenities in it. This way his burlesque manner 
in both volumes of the novel does not transcend carnival context, and thus does not become satirical. The same continues in his further series Shydevry svitovoi literatury [Masterpieces of World Literature] and Shydevry ukrainskoi literatury [Masterpieces of Ukrainian Literature], which were published after 2010, and are comic revisions of the chief literary "great books." Yuri Vynnychuk, Les Poderviansky, Mykhailo Brynykh, as well as other similar less known authors, continue to write actively in the described manners even nowadays, which makes it possible to make a conclusion about the further development of the Ukrainian burlesque literature tradition, either in its carnival variant, or in the satirical one.

Consequently, an influential burlesque tradition has existed and developed in Ukrainian literature since the folk carnival rituals and vagabond cantors, from Ivan Kotliarevsky and Hryhorii Kvitka-Osnovianenko to Stepan Rudansky and Ostap Vyshnia, and further to our contemporaries Yuri Andrukhovych, Yuri Vynnychuk, Les Poderviansky, and Mykhailo Brynykh. This tradition preserves the heritage of carnival laughter, which is the explosion of vital energy that reverses and overthrows everything and everyone in an attempt to renew and recreate the world around. This joyful and deliberate laughter exists alongside with the satirical tradition. In Ukrainian literature burlesque survived totalitarian repression, is not forgotten, and returned with a double strength after society became more liberal. It remains one of the most powerful streams that nourishes and fuels our national literature and culture.

\section{Bibliography}

Bakhtin, Mikhail. Tvorchestvo Fransua Rable i narodnaia kultura srednevekovia i Renesansa [François Rabelais' Works and Folk Culture of the Middle Ages and Renaissance]. Moscow: Khudozhestvennaia literatura, 1990.

Freid, Zigmund. Ostroumiie i ieho otnosheniie kbessoznatielnomu [The Joke and its Relation to the Unconscious]. Moscow: AST; Minsk: Kharvest, 2006.

Habor, Vasyl, ed. Bu-Ba-Bu (Andrukhovych, Irvanets, Neborak). Lviv: Piramida, 2007.

Habor Vasyl, ed. Ukrainski literaturni shkoly ta hrupy 6o-9o rr. XX st. [Ukrainian Literary Schools and Groups of the 1960s-199os]. Lviv: Piramida, 2009.

Hrabovych, Hryhorii. Semantyka kotliarevshchyny [The Semantics of kotliarevshchyna]. Accessed December 18, 2014. http://izbornyk.org.ua/hrabo/hri4.htm.

Hundorova, Tamara. Kitch i literatura [Kitsch and Literature]. Kyiv: Fakt, 2008.

Hutcheon, Linda. A Theory of Parody. The Teachings of Twentieth Century Art Forms. London: Methuen, 1985 .

Kovaliv, Iurii. Literaturoznavcha encyclopediia [Literary Criticism Encyclopedia]. 2 vol. Kyiv: Academiia, 2007.

Nudha, Hryhorii, ed. Burlesk i travestiia v ukrainskii poezii pershoi polovyny XIX st. [Burlesque and Travesty in Ukrainian Poetry of the First Half of the 19th Century]. Kyiv: Derzhavne vydavnytstvo khudozhnioi literatury, 1959.

Poltoratsky, Oleksii. “Scho take Ostap Vyshnia?” [“Who is Ostap Vyshnia?”] Nova Heneratsia 2-4 (1930): $28-32$. 
Rose, Margaret. Parody: Ancient, Modern, and Post-modern. Cambridge: Cambridge University Press, 1993.

Semkiv, Rostyslav. "Yuri Vynnychuk iak tsentralna postat halytskoii burlesknoii literatury." ["Yuri Vynnychuk as the Central Figure of Galician Burlesque Literature."] In Pislia postmodernizmy, edited by Vira Aheyeva, 83-98. Kyiv: NaUKMA; Ahrar Media Hrup, 2012.

Struc, Roman. "Pushkin, Lermontov, Gogol: Ironic Modes in Russian Romanticism." In Romantic Irony, edited by Frederick Garber, 241-49. Budapest: Akadémiai Kiadô, 1988.

\section{讨}

Rostyslav Semkiv is currently Associate Professor at the National University of Kyiv-Mohyla Academy. In 2003, he defended his PhD dissertation Irony as the Principle of Fictional Structure, and since then teaches at Kyiv-Mohyla Academy, lecturing in Literary Criticism, Comparative Literature, Contemporary Methods of Humanities Research, American Cyberpunk Literature, and Satire and Humour in European Literatures. 